\title{
Distribution and characteristic of nitrite-dependent anaerobic methane oxidation bacteria in wastewater treatment plants and agriculture fields in northern China
}

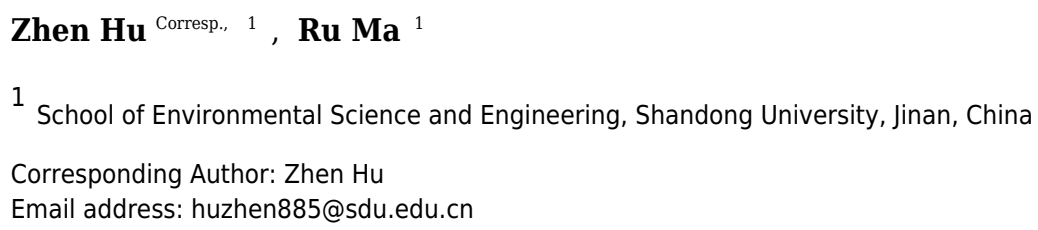

Nitrite-dependent anaerobic methane oxidation (n-damo) is a recently discovered biological process, which has been arousing global attention because of its potential in minimizing greenhouse gases emissions. In this study, molecular biological techniques and potential n-damo activity batch experiments were conducted to investigate the presence and diversity of $M$. oxyfera bacteria in paddy field, corn field, and wastewater treatment plant (WWTP) of northern China, as well as lab-scale n-damo enrichment culture. N-damo enrichment culture showed the highest abundance of $M$. oxyfera bacteria and positive correlation was observed between potential $n$-damo rate and abundance of $M$. oxyfera bacteria. Both paddy field and corn field were believed to be better inoculum than WWTP for the enrichment of $M$. oxyfera bacteria, due to their higher abundance and diversity of M. oxyfera bacteria. Comparative analysis revealed that long biomass retention time, low $\mathrm{NH}_{4}{ }^{+}$and high $\mathrm{NO}_{2}{ }^{-}$content were suitable for the growth of $M$. oxyfera bacteria. 
1 Distribution and characteristic of nitrite-dependent anaerobic methane oxidation bacteria by

2 comparative analysis of wastewater treatment plants and agriculture fields in northern China

3 Zhen $\mathrm{Hu}^{\mathrm{a}, *}$, Ru Ma ${ }^{\mathrm{a}}$

4 a School of Environmental Science and Engineering, Shandong University, Jinan, Shandong, China.

5 Corresponding Author:

6 Zhen $\mathrm{Hu}$

7 No. 27 Shanda South Road, Jinan, Shandong 250100,China

8 E-mail: huzhen885@sdu.edu.cn

9 


\section{Introduction}

11 Methane $\left(\mathrm{CH}_{4}\right)$ and nitrous oxide $\left(\mathrm{N}_{2} \mathrm{O}\right)$ are important greenhouse gases, accounting for about $20 \%$ and $7 \%$ of

12 global warming, respectively (Griggs \& Noguer 2002; Knittel \& Boetius 2009). Cai (2012) reported that

13 anthropogenic activities, rather than natural sources, are the major sources of $\mathrm{CH}_{4}$ and $\mathrm{N}_{2} \mathrm{O}$ emissions. And it

14 is widely accepted that wastewater treatment plants (WWTPs) and agricultural fields are two of the most

15 important anthropogenic GHGs sources (Foley et al. 2011; Liu et al. 2014a). In WWTPs, enormous amount of

$16 \mathrm{CH}_{4}$ and $\mathrm{N}_{2} \mathrm{O}$ would be produced during the biological transformation of carbohydrates and nitrogenous

17 compounds, respectively. Our previous on-site investigation showed that about $4.48-9.68 \times 10^{9} \mathrm{~g}$ of $\mathrm{CH}_{4}$ and

$180.93-1.28 \times 10^{9} \mathrm{~g}$ of $\mathrm{N}_{2} \mathrm{O}$ would be emitted from WWTPs of China per year (Wang et al. 2011a; Wang et al.

19 2011b). And compared with WWTPs, agricultural field was believed to be more important GHGs sources,

20 mainly because the widely usage of chemical fertilizers to improve the productivity (IPCC, 2001). It is

21 reported that agriculture field would contribute to $60 \%$ of $\mathrm{N}_{2} \mathrm{O}$ and $50 \%$ of $\mathrm{CH}_{4}$ emissions on a global scale

22 (Montzka et al. 2011; Syakila \& Kroeze 2011).

23 Anaerobic methane oxidation (AMO) is a recently discovered sink of methane on earth, with a

24 consumption rate of approximately 70-300 $\mathrm{Tg} \mathrm{CH}_{4}$ year-1 globally (Cui et al. 2015; Hu et al. 2011). Besides

25 AMO coupled to reduction of sulfate (Timmers et al, 2015; Bian et al. 2001), humic compound (Smemo \& 
26 Yavitt 2007), iron (Beal et al. 2009; Segarra et al. 2013) and manganese (Egger et al. 2015), the coupling of

27 AOM to nitrite reduction process, named as nitrite-dependent anaerobic methane oxidation (n-damo), has

28 also been demonstrated (Raghoebarsing et al. 2006). N-damo process is performed by "Candidatus

29 Methylomirabilis oxyfera" (M. oxyfera) bacteria, which is affiliated with the NC10 phylum (Ettwig et al.

30 2010). N-damo process established a unique relationship between carbon cycle and nitrogen cycle

31 (Raghoebarsing et al. 2006), and it was believed to be a promising method to minimize greenhouse gases

32 emissions through converting $\mathrm{CH}_{4}$ and $\mathrm{N}_{2} \mathrm{O}$ to $\mathrm{CO}_{2}$ and $\mathrm{N}_{2}$, respectively (Raghoebarsing et al. 2006; Shen et

33 al. 2015).

34 Presently, many studies have focused on the distribution of M. oxyfera bacteria in natural environment, e.g.,

35 freshwater lakes (Liu et al. 2014b), paddy soil (Wang et al. 2012), marine sediments (Chen et al. 2014),

36 wetlands (Hu et al. 2014b), and etc. However, to date, information about distribution of M. oxyfera bacteria in

37 northern China is still lacking. In addition, various inoculums have been reported to be able to enrich $M$.

38 oxyfera bacteria successfully, including freshwater sediment (Raghoebarsing et al. 2006), sewage treatment

39 sludge (Luesken et al. 2011a), ditch sediments (Ettwig et al. 2009) and paddy soil (Shen et al. 2014a; Wang et

40 al. 2012). He et al. (2014) found that inoculum sources had significant effect on enrichment of M. oxyfera

41 bacteria, and claimed that paddy soil was the optimal inoculum. However, intensive study on inoculum sources

42 from the perspective of microorganism is absence. 
43 In this study, the presence and diversity of M. oxyfera bacteria in four different sites of northern China, i.e.,

44 paddy field, corn field, WWTP and n-damo enrichment culture, were investigated through molecular biological

45 techniques and potential n-damo activity batch experiments. Comparative analysis of environmental features

46 and $M$. oxyfera bacteria activity was conducted to reveal the characteristics of $M$. oxyfera bacteria, as well as

47 its optimal growth conditions.

48 Materials and methods

\section{Site description and sample collection}

50 Non-flooded paddy field with rice reaping once per year (PF) and corn field with maize-wheat rotation for over

5150 years (CF), both of which are typical agricultural type of northern China, were selected as agricultural field

52 sample sites. PF cores and CF cores were collected from three locations ( $5 \mathrm{~m}$ distance) at the $50-60 \mathrm{~cm}$ depth in

53 each sampling site, according to the previously described methods (Hu et al. 2014b). Sludge from anaerobic

54 tank of local WWTP (Everbright Water, Jinan China) (WS), and lab-scale Upflow Anaerobic Sludge Bed

55 reactor (UASB) aiming at enrichment of M.oxyfera bacteria (EC), were selected as WWTP samples. The

56 sample collection was conducted in October, 2015, and the environmental characteristics of each sample site

57 are listed in Table 1.

58 All collected samples were placed in hermetic containers and immediately transported to the laboratory 
59 within $4 \mathrm{~h}$. Subsequently, the collected samples were equally divided into three parts. The first part was placed

60 in the incubator to measure the potential n-damo activity, the second parts was stored in refrigerator at $4^{\circ} \mathrm{C}$ for

61 analysis of physicochemical parameters, and the last part was stored in refrigerator at $-20^{\circ} \mathrm{C}$ for further

62 microbiological analysis.

63 Table 1. Environmental characteristics of the sample sites.

\section{Physicochemical parameters analysis}

65 Soil samples were extracted with $1 \mathrm{M} \mathrm{KCl}$ and the concentrations of ammonium, nitrite and nitrate were

66 measured as described by Ryan et al. (2007). Soil $\mathrm{pH}$ was measured at soil/water ratio of 1:2.5 using a pH

67 analyzer (HQ30d 53LEDTM, HACH, USA) (Wang et al. 2012). Temperature and salinity of soil was

68 measured in situ using HI98331 soil electrical conductivity meter (HI98331, HANNA, Shanghai).

69 Concentrations of ammonium, nitrite and nitrate in water samples were analyzed according to the standard

70 method (APHA, 2005). Water temperature, $\mathrm{pH}$ and salinity were measured in situ using $\mathrm{pH}$ and salinity

71 analyzer (DDBJ-350, Leici, Shanghai). And $\mathrm{CH}_{4}$ concentration in gas phase was analyzed using gas

72 chromatograph equipped with flame ionization detector (FID-GC) (7890B, Agilent Technologies, USA).

\section{Potential n-damo activity batch experiment}


74 All the samples were washed three times with anaerobic water to remove the residual $\mathrm{NO}_{\mathrm{x}}{ }^{-}\left(\mathrm{NO}_{2}{ }^{-}\right.$and $\left.\mathrm{NO}_{3}{ }^{-}\right)$

75 and organic compounds, and were then transferred to $1 \mathrm{~L}$ Ar-flushed glass bottles. The slurries were pre-

76 incubated under anoxic conditions at $32 \pm 1{ }^{\circ} \mathrm{C}$ for at least $48 \mathrm{~h}$, in order to let the microbes adapt to the new

77 environment. The bottle was flushed with Ar gas again before the measurement of potential n-damo activity. Two

78 treatment groups were conducted subsequently: (a) $\mathrm{CH}_{4}$ (blank group), (b) $\mathrm{CH}_{4}+\mathrm{NO}_{2}-$ (experimental group).

79 The initial $\mathrm{CH}_{4}$ concentrations in both blank and experimental groups were $1.02 \pm 0.06 \mathrm{mmol} \mathrm{L}^{-1}$ and the initial

80 concentrations of $\mathrm{NO}_{2}^{-}$in the experimental groups were $0.35 \pm 0.01 \mathrm{mmol} \mathrm{NO}_{2}^{-} \mathrm{L}^{-1}$. The variation of $\mathrm{CH}_{4}$ and

$81 \mathrm{NO}_{2}^{-}$concentrations were determined at intervals of 6 hours. The potential methane oxidation rates and the

82 ratio of $\mathrm{CH}_{4} / \mathrm{NO}_{2}^{-}$were evaluated by linear regression of $\mathrm{CH}_{4}$ and $\mathrm{NO}_{2}{ }^{-}$decrease in the experimental groups.

\section{Fluorescence in situ hybridization (FISH)}

84 Approximately $0.3 \mathrm{~g}$ of collected samples were washed in phosphate-buffered saline (PBS; $10 \mathrm{mM}$

$85 \mathrm{Na}_{2} \mathrm{HPO}_{4} / \mathrm{NaH}_{2} \mathrm{PO}_{4} \mathrm{pH} 7.5$ and $\left.130 \mathrm{mM} \mathrm{NaCl}\right)$ and fixed with $4 \%$ (w/v) paraformaldehyde in PBS for $3 \mathrm{~h}$ under

$864^{\circ} \mathrm{C}$. After incubation, the sediment (fixed biomass) was washed with PBS and then stored in mixture (1 $\left.\mathrm{ml}\right)$ of

87 ethanol and PBS $(1 \times)$ at $-20^{\circ} \mathrm{C}$ until analysis.

88 Bacterial probe S-*-DBACT-1027-a-A-18 (5'-TCTCCACGCTCCCTTGCG-3') (Cy3, red), specific for

89 bacteria affiliated with the NC10 phylum were used in this study (Raghoebarsing et al. 2006); and a mixture of 
90 EUB I-III (FITC, green) was used for the detection of total bacteria (Daims et al. 1999). Fixed biomass (10 $\mu$ l)

91 was spotted on microscopic slides circles and then dehydrated subsequently with $50 \%, 80 \%$, and $98 \%$ of

92 ethanol for $3 \mathrm{~min}$ each. The probes were hybridized for $2 \mathrm{~h}$ at $46{ }^{\circ} \mathrm{C}$ in hybridization buffer $(5 \mathrm{M} \mathrm{NaCl}, 1 \mathrm{M}$

93 Tris/ $\mathrm{HCl} \mathrm{pH} \mathrm{8.0,} \mathrm{10 \%} \mathrm{sodium} \mathrm{dodecyl} \mathrm{sulfate)} \mathrm{and} \mathrm{40 \%} \mathrm{formamide.} \mathrm{Hybridized} \mathrm{samples} \mathrm{were} \mathrm{washed} \mathrm{with}$

94 hybridization leachate at $48^{\circ} \mathrm{C}$ and then added with the fluorescence decay resistance agent. Fluorescence

95 microscope (BX53, Olympus, Japan) was used to observe the prepared slides and the picture was disposed

96 with Image-Pro Plus 6.0.

\section{DNA extraction and PCR amplification}

98 Total DNA was extracted using Power Soil DNA Isolation kit (Mo Bio Laboratories, Carlsbad, CA) according

99 to the manufacturer's protocols. And DNA concentration was measured at $260 \mathrm{~nm}$ with Nano-drop

100 spectrophotometer (NanoDrop 1000, Nano-Drop Technologies, USA).

101 To understand the biodiversity of $M$. oxyfera bacteria, 16S rRNA gene of $M$. oxyfera bacteria was

102 amplified using nested PCR protocols, as previously described (Hu et al. 2014b; In nested PCR, products of

103 the first round PCR were then used as the DNA templates in the following round PCR. For 16S rRNA gene

104 amplification, specific forward primer 202F (Ettwig et al. 2009) and general bacterial reverse primer 1545R

105 (Juretschko et al. 1998) were used for the first round PCR, NC10 specific primers qP1F and qP2R (Ettwig et 
106 al. 2009) were performed for the second round PCR. The detailed information of nested PCR is shown in

107 Table S1.

108 Quantitative Real-Time PCR (qPCR)

109 The quantitative PCR of M. oxyfera bacteria 16S rRNA gene were performed on LightCycler480 with

110 Sequence Detection Software v1.4 (Applied Biosystems, Life Technologies Corporation, USA). The

111 abundance of 16S rRNA gene was determined using the primers qp1R-qp1F (Ettwig et al. 2009) with $10 \mu \mathrm{L}$

112 of Power SYBR Green PCR Master Mix, $1 \mu \mathrm{L}$ of template DNA (5-20 ng $\left.\mu \mathrm{L}^{-1}\right), 0.4 \mu \mathrm{L}$ of each primer and

$1138.2 \mu \mathrm{L}$ of $\mathrm{ddH}_{2} \mathrm{O}$. Detailed information is exhibited in Table S1. Negative-control reactions in which the

114 DNA template was replaced by nuclease-free water were also performed. The whole process was performed

115 under sterile conditions on ice and away from light. Triplicate qPCR analyses were performed for each

116 sample. The standard curve was constructed from purified plasmid DNA with the concentrations ranging

117 from $1.0 \times 10^{1}$ to $1.0 \times 10^{7}$ copies $\mu \mathrm{L}^{-1}$, and it showed correlation between the DNA template concentration

118 and the crossing point with coefficients of determination $\left(\mathrm{R}^{2}>0.97\right)$. The $\mathrm{qPCR}$ amplification efficiency of the

119 standard curve and reactions were both greater than $85 \%$.

\section{High-throughput pyrosequencing and data analysis}


121 After amplification, the purified nested PCR products of 16S rRNA gene were used for pyrosequencing on

122 the Roche 454 GS-FLX Titanium sequencer (Roche 454 Life Sciences, Branford, CT, USA) at Personalbio

123 (Shanghai Personal Biotechnology, Co., Ltd., Shanghai, China).

124 After pyrosequencing, all the raw reads were analyzed using QIIME standard pipeline (Shu et al. 2015),

125 to trim off the low quality reads, adaptors, barcodes and primers. Then sequences containing ambiguous base

126 calls (Ns) and sequences shorter than $150 \mathrm{bp}$ were also removed. The remaining sequences were clustered

127 into operational taxonomic unites (OTUs) by UCLUST, with identity of 97\% (Edgar et al. 2011). The

128 sequences with highest relative abundance in each OUT were annotated with NCBI taxonomy using

129 BLASTN and the Green genes database. Chaol richness estimator, ACE estimator, Simpson diversity and

130 Good's coverage were calculated in Mothur analysis (http://www.mothur.org). Beta diversity statistics,

131 including cluster analysis, weighted UniFrac distance metrics, and Principal coordinate analysis (PCoA),

132 were conducted based on UniFrac metric (Zhang et al., 2011).

133 Ethical Statement This article does not contain any studies with human participants or animals performed

134 by any of the authors.

\section{Results}




\section{Physicochemical Characteristics of the Sample Sites}

137 Significant differences in physicochemical characteristics among different environmental samples were

138 observed in the present study. The peak $\mathrm{NH}_{4}{ }^{+}-\mathrm{N}$ content $\left(815.88 \mathrm{mg} \mathrm{N} \mathrm{kg}{ }^{-1}\right.$ dry sediment) was detected in WS,

139 which was over 80 -folds higher than that in the other three sample sites. And the highest $\mathrm{NO}_{2}^{-}-\mathrm{N}$ content

140 (14120 mg N kg${ }^{-1}$ dry sediment) was observed in EC, while $\mathrm{NO}_{2}^{-}-\mathrm{N}$ content in the other three sample site

141 varied form $0.37-127.19 \mathrm{mg} \mathrm{N} \mathrm{kg}{ }^{-1}$ dry sediment. Mainly because of its high $\mathrm{NO}_{2}^{-}$content, the highest $\mathrm{NO}_{\mathrm{x}}{ }^{-}-\mathrm{N}$

142 content was also observed in EC, which was beyond 17-folds higher than that of the other three sample sites. In

143 addition, compared with published researches conducted in paddy fields, where $\mathrm{NO}_{\mathrm{X}}{ }^{-} \mathrm{N}$ content was around

$1441.4-3.3 \mathrm{mg} \mathrm{N} \mathrm{kg}^{-1}$ dry sediment ( Shen et al. 2014a; Zhou et al. 2014 ; Ding et al. 2015), higher $\mathrm{NO}_{\mathrm{X}}{ }^{-} \mathrm{N}$

145 content in the agriculture field (PF and CF) of northern China was observed in this study, mainly caused by

146 difference in farming methods.

\section{Abundance of M.oxyfera bacteria}

148 FISH analysis was used to investigate the spatial distribution and relative quantification of $M$. oxyfera bacteria

149 compared to total bacteria. As shown in Fig. 1, M. oxyfera bacteria (represented by red color) were observed in

150 all four sample sites, and the proportion of M. oxyfera bacteria to total bacteria followed the order of 
151 EC $>$ PF $>$ CF $>$ WS. Notably, compared with total bacteria, M. oxyfera bacteria in the enrichment culture took up

152 over 50\%, indicating the predominance of M.oxyfera bacteria.

153 To further accurately quantify the abundance of $M$. oxyfera bacteria, qPCR analysis was conducted and

154 significant difference was also observed in different sampling sites. The abundance of $M$. oxyfera bacteria were

$1557.28 \pm 0.8 \times 10^{7}, 1.55 \pm 0.3 \times 10^{7}, 1.07 \pm 0.3 \times 10^{10}, 2.61 \pm 0.1 \times 10^{6}$ copies per gram of dry sediment in PF, CF, EC and

156 WS, respectively (Fig.2). This order was in consistence with results of FISH analysis.

157 Fig. 1 FISH image of the collected samples. The M. oxyfera bacteria was hybridized with probe S-*-DBACT-1027-a-A-18(Cy3,

158 red) and total bacteria was hybridized with probes EUB I-III (FITC, green). a\&e, PF; b\&f, CF; c\&g, EC, d\&h, WS. The scale

159 bar indicates $100 \mu m$.

160 Fig. 2 The abundance of M. oxyfera bacteria in different sample sites.

\section{Potential Rates of n-damo Activity}

162 In order to estimate the activity of M. oxyfera bacteria, batch experiments were conducted using the collected

163 samples, and the results are shown in Fig. 3. In experimental groups amended with $\mathrm{CH}_{4}$ and $\mathrm{NO}_{2}^{-}$, dramatic

164 decline in $\mathrm{CH}_{4}$ concentration were observed compared with the blank groups, indicating that $\mathrm{CH}_{4}$ oxidation

165 was propelled by $\mathrm{NO}_{2}^{-}$reduction under anoxic conditions. The detected anaerobic methane oxidizing rates

166 were $3.90 \pm 0.05,2.58 \pm 0.08,22.31 \pm 0.02$ and $1.61 \pm 0.01 \mu \mathrm{mol} \mathrm{CH}_{4} \mathrm{~g}^{-1} \mathrm{~d}^{-1}$ in PF, CF, EC and WS, respectively.

167 The stoichiometric ratio for methane to nitrite, calculated through the curve fitting method, were 3:5.7 for PF, 
168 3:4.6 for CF, 3:6.9 for EC, and 3:3.2 for WS. The value of n-damo enrichment culture was the closest to the

169 theoretical stoichiometric ratio, which was 3:8 (Ettwig et al. 2010).

170 Fig. 3 The consumption rates of methane and nitrite in the paddy field (a), corn field (b), n-damo enrichment culture (c), WWTP

$171(d)$

\section{Microbial community structure analysis}

173 In order to determine the microbial community structure of different samples, 454 high-throughput sequencing

174 analysis of 16S rRNA gene was conducted. Raw reads obtained from different samples ranged from 11017 to

17514814 and the good coverage values varied from $86.48 \%$ to $94.70 \%$ (Table S2), indicating that these sequences

176 were enough to analyze the microbial community structures. Chaol estimator, ACE estimator, Shannon index

177 and the numbers of OTUs in four samples followed the same order, which was $\mathrm{PF}>\mathrm{CF}>\mathrm{EC}>\mathrm{WS}$ (Table S2).

178 To show the diversity of species among different samples, rarefaction curves were drawn in this study

179 (Fig. S1). Results showed that the rarefaction curves of all samples didn't reach a saturation stage, indicating

180 that these samples had highly diverse microbial communities. PCoA was conducted to investigate the

181 differences in microbial community between different samples, based on unweighted UniFrac distance metrics.

182 Results showed that PF and CF tended to cluster together, while EC and WS were obviously different. The

183 results with maximum variation of $87.59 \%(\mathrm{PC} 1)$ and $8.37 \%$ (PC2) were shown in Fig. S2. 
184 The difference in microbial community of four samples at the phylum level is shown in Fig. 4. A total of

18516 phyla were identified and $\mathrm{NC10}$ was the main phylum observed in PF, CF and EC, accounting for $74.4 \%$,

$18692.2 \%$ and $65.2 \%$ of total microorganism, respectively, while Armatimonadetes (formerly candidate division

187 OP10) was the dominant phylum in WS and NC10 phylum only accounted for $7.1 \%$ of total microorganism

188 in WS. Since not all NC10 phylum bacteria were defined as M.oxyfera bacteria (Ettwig et al., 2009; Wang et

189 al. 2015), for better understanding and analysis the diversity of $M$. oxyfera bacteria in different samples, heat

190 map was conducted at the genera level and the results is shown in Fig. 5. Candidatus.Methylomirabilis

191 bacteria, which were proved to be able to complete n-damo process (Ettwig et al. 2010), accounted for 1.00\%,

$1921.47 \%, 1.80 \%$ and $0.057 \%$ of total microorganism in PF, CF, EC and WS, respectively. All these sequences,

193 which were identified as Candidatus.Methylomirabilis, were grouped into 8 (PF), 17 (CF), 9 (EC) and 3 (WS)

194 OTUs at the $97 \%$ identity level.

195 Fig. 4 Composition of microbial community at phylum level in different samples.

196 Fig. 5 Richness heat map of the 25 most abundant genera.

\section{Discussion}

198 In present study, PF, CF, EC and WS in northern China, as previously overlooked sites, were selected to 
200 potential n-damo activity, as well as the highest abundance of M. oxyfera bacteria. Correlation analysis

201 showed that the potential n-damo rates and the abundance of $M$. oxyfera bacteria followed the same

202 descending order, i.e., $\mathrm{EC}>\mathrm{PF}>\mathrm{CF}>\mathrm{WS}$, indicating positive correlation between the two indexes. Moreover,

203 the potential $\mathrm{n}$-damo rate $\left(22.31 \pm 0.02 \mu \mathrm{mol} \mathrm{CH}_{4} \mathrm{~g}^{-1} \mathrm{~d}^{-1}\right)$ of EC was higher than that reported in other $\mathrm{n}$-damo

204 enrichment culture (He et al. 2014). This was attributed to the relative higher abundance of M. oxyfera

205 bacteria in the present study. The abundance of M. oxyfera bacteria in the present study was over 20 times

206 higher than that reported by He et al. (2014), which further verified the positive correlation between the

207 potential n-damo rates and the abundance of M. oxyfera bacteria.

208 WWTP showed lower abundance of $M$. oxyfera bacteria than the other three sample sites, mainly because

209 of its short biomass retention time (13 days), while biomass retention time of other three sample sites was

210 years or even decades of years (Kampman et al. 2014; Weiland BP. 2006). With the doubling time of 1-2

211 weeks (Ettwig et al. 2009), the growth rate of M. oxyfera bacteria is much lower than heterotrophic bacteria,

212 indicating that M. oxyfera bacteria might be washed out in WWTP and resulted in lower abundance of $M$.

213 oxyfera bacteria. Another possible reason was that high $\mathrm{NH}_{4}^{+}$content in WWTP, which was unfavorable for

214 the growth of $M$. oxyfera bacteria. Winkler et al. (2015) found that anammox bacteria had advantage over $M$.

215 oxyfera bacteria for nitrite in the presence of excess ammonium. What is more interesting, although WS was

216 used as initial inoculum for EC in this study, the abundance of M. oxyfera bacteria in EC was over $4 \times 10^{3}$ 
217 times higher than that in WS. This was mainly attributed to a combination of low $\mathrm{NH}_{4}{ }^{+}$content and high

$218 \mathrm{NO}_{2}^{-}$content during the enrichment period of EC. It was reported that the nitrite affinity constant of $M$

219 .oxyfera bacteria was $0.6 \mathrm{~g} \mathrm{NO}_{2}^{-}-\mathrm{Nm}^{-3}$, indicating that high $\mathrm{NO}_{2}^{-}$content was more beneficial for the growth

220 of M.oxyfera bacteria (Winkler et al. 2015).

221 The distribution and composition of NC10 phylum was determined by 16S rRNA gene sequencing

222 analysis. NC10 phylum detected from PF, CF and EC were significant higher than that in WS, which was

223 mainly attributed to short biomass retention time of WWTP. In addition, it can be seen from the heat map that

224 the abundance of $M$. oxyfera bacteria in different samples followed the order of $\mathrm{EC}>\mathrm{PF}>\mathrm{CF}>\mathrm{WS}$, which was

225 consistence with the result of qPCR. What's more, PF and CF had much higher OTU numbers than WS. Thus,

226 it was believed that PF and CF could be favorable inoculum for the enrichment of M. oxyfera bacteria, due to

227 their higher abundance and diversity of $M$. oxyfera bacteria. And it's worth to notice that significant

228 difference existed in microbial community between EC and WS, EC has 6 more OTUs than WS, although

229 WS was used as initial inoculum for EC. This might be caused by the optimum enrichment culture for $M$.

230 oxyfera bacteria in EC, i.e., low $\mathrm{NH}_{4}{ }^{+}$and high $\mathrm{NO}_{2}{ }^{-}$contents. Besides, the increase in diversity of M. oxyfera

231 bacteria would also be attributed to the longer biomass retention time of EC.

232 In conclusion, the present study further expanded our knowledge on distribution and characteristic of $M$.

233 oxyfera bacteria in northern China. Comparative analysis found that positive correlation existed between 
234 abundance of $M$. oxyfera bacteria and potential n-damo activity rate. In addition, PF and CF were identified as

235 suitable inocula to enrich M. oxyfera bacteria. Moreover, long biomass retention time, low $\mathrm{NH}_{4}{ }^{+}$and high $\mathrm{NO}_{2}{ }^{-}$

236 contents would benefit the growth of $M$. oxyfera bacteria.

\section{References}

238 APHA. 2005. Standard methods for the examination of water and wastewater. American Public Health

239 Association (APHA): Washington, DC, USA.

240 Bian L, Hinrichs K-U, Xie T, Brassell SC, Iversen N, Fossing H, Jørgensen BB, and Hayes JM. 2001. Algal

241 and archaeal polyisoprenoids in a recent marine sediment: Molecular isotopic evidence for anaerobic

242 oxidation of methane. Geochemistry, Geophysics, Geosystems 2:n/a-n/a. 10.1029/2000gc000112

243 Cai Z. 2012. Greenhouse gas budget for terrestrial ecosystems in China. Science China Earth Sciences 55:173-

244

182. $10.1007 / \mathrm{s} 11430-011-4309-8$

245 Chen J, Jiang X-W, and Gu J-D. 2014. Existence of Novel Phylotypes of Nitrite-Dependent Anaerobic

246 Methane-Oxidizing Bacteria in Surface and Subsurface Sediments of the South China Sea.

$247 \quad$ Geomicrobiology Journal 32:1-10. 10.1080/01490451.2014.917742

248 Cui M, Ma A, Qi H, Zhuang X, and Zhuang G. 2015. Anaerobic oxidation of methane: an "active" microbial

$249 \quad$ process. MicrobiologyOpen 4:1-11. 10.1002/mbo3.232

250 Daims H, Brühl A, Amann R, Schleifer K-H, and Wagner M. 1999. The Domain-specific Probe EUB338 is

251 Insufficient for the Detection of all Bacteria: Development and Evaluation of a more Comprehensive

252 Probe Set. Systematic and Applied Microbiology 22:434-444. 10.1016/s0723-2020(99)80053-8

253 Deutzmann JS and Schink B. 2011. Anaerobic oxidation of methane in sediments of Lake Constance, an 
254 oligotrophic freshwater lake. Appl Environ Microbiol. p 4429-4436.

255 Ding J, Fu L, Ding ZW, Lu YZ, Cheng SH and Zeng RJ. 2015. "Environmental evaluation of coexistence of 256 denitrifying anaerobic methane-oxidizing archaea and bacteria in a paddy field." Appl Microbiol 257 Biotechnol 100(1): 439-446.

258 Edgar RC, Haas BJ, Clemente JC, Quince C, and Knight R. 2011. UCHIME improves sensitivity and speed of 259 chimera detection. Bioinformatics 27:2194-2200.

260 Egger M, Rasigraf O, Sapart CJ, Jilbert T, Jetten MSM, Röckmann T, van der Veen C, Bândă N, Kartal B, 261 Ettwig KF, and Slomp CP. 2015. Iron-Mediated Anaerobic Oxidation of Methane in Brackish Coastal Sediments. Environmental Science \& Technology 49:277-283. 10.1021/es503663z

263 Emily J. Beal CHH, Victoria J. Orphan. 2009. Manganese- and Iron-Dependent Marine Methane Oxidation.

264 Ettwig KF, Butler MK, Le Paslier D, Pelletier E, Mangenot S, Kuypers MM, Schreiber F, Dutilh BE, Zedelius J, de Beer D, Gloerich J, Wessels HJ, van Alen T, Luesken F, Wu ML, van de Pas-Schoonen KT, Op den Camp HJ, Janssen-Megens EM, Francoijs KJ, Stunnenberg H, Weissenbach J, Jetten MS, and Strous M. 2010. Nitrite-driven anaerobic methane oxidation by oxygenic bacteria. Nature 464:543548. $10.1038 /$ nature 08883

Ettwig KF, van Alen T, van de Pas-Schoonen KT, Jetten MSM, and Strous M. 2009. Enrichment and Molecular Detection of Denitrifying Methanotrophic Bacteria of the NC10 Phylum. Applied and DK, West PC, Balzer C, Bennett EM, Carpenter SR, Hill J, Monfreda C, Polasky S, Rockstrom J, 
276 Griggs DJ, and Noguer M. 2002. Climate change 2001: the scientific basis. Contribution of working group I to

277 the third assessment report of the intergovernmental panel on climate change. Weather 57:267-269.

278 He Z, Cai C, Shen L, Lou L, Zheng P, Xu X, and Hu B. 2014. Effect of inoculum sources on the enrichment of 279 nitrite-dependent anaerobic methane-oxidizing bacteria. Appl Microbiol Biotechnol 99:939-946.

$280 \quad 10.1007 / \mathrm{s} 00253-014-6033-8$

281 He Z, Geng S, Shen L, Lou L, Zheng P, Xu X, and Hu B. 2015. The short- and long-term effects of 282 environmental conditions on anaerobic methane oxidation coupled to nitrite reduction. Water $283 \quad$ Research 68:554-562. 10.1016/j.watres.2014.09.055

284 Hu B, He Z, Geng S, Cai C, Lou L, Zheng P, and Xu X. 2014a. Cultivation of nitrite-dependent anaerobic 285

286 methane-oxidizing bacteria: impact of reactor configuration. Appl Microbiol Biotechnol 98:7983-7991.

287

Hu BL, Shen LD, Lian X, Zhu Q, Liu S, Huang Q, He ZF, Geng S, Cheng DQ, Lou LP, Xu XY, Zheng P, and He YF. 2014b. Evidence for nitrite-dependent anaerobic methane oxidation as a previously

289 overlooked microbial methane sink in wetlands. Proc Natl Acad Sci U S A 111:4495-4500.

290 $10.1073 /$ pnas. 1318393111

291 Hu S, Zeng RJ, Keller J, Lant PA, and Yuan Z. 2011. Effect of nitrate and nitrite on the selection of

292 microorganisms in the denitrifying anaerobic methane oxidation process. Environ Microbiol Rep

293 3:315-319. 10.1111/j.1758-2229.2010.00227.x

294 Intergovernmental Panel on Climate Change (IPCC), Third Assessment Report. Working Group I, Cambridge 295 Univ. Press, New York, 2001.

296 Juretschko S, Timmermann G, Schmid M, Schleifer K-H, Pommerening-Röser A, Koops H-P, and Wagner M. 1998. Combined molecular and conventional analyses of nitrifying bacterium diversity in activated 

environmental microbiology 64:3042-3051.

300 Kampman C, Temmink H, Hendrickx TLG, Zeeman G, and Buisman CJN. 2014. Enrichment of denitrifying methanotrophic bacteria from municipal wastewater sludge in a membrane bioreactor at $20^{\circ} \mathrm{C}$. Journal

302 of Hazardous Materials 274:428-435. 10.1016/j.jhazmat.2014.04.031

303 Knittel K, and Boetius A. 2009. Anaerobic Oxidation of Methane: Progress with an Unknown Process. Annual Review of Microbiology, 311-334.

305 Liu Y, Cheng X, Lun X, and Sun D. 2014a. CH4 emission and conversion from A2O and SBR processes in 306 full-scale wastewater treatment plants. Journal of Environmental Sciences 26:224-230.

307 http://dx.doi.org/10.1016/S1001-0742(13)60401-5

Liu Y, Zhang J, Zhao L, Li Y, Yang Y, and Xie S. 2014b. Aerobic and nitrite-dependent methane-oxidizing microorganisms in sediments of freshwater lakes on the Yunnan Plateau. Appl Microbiol Biotechnol

311 99:2371-2381. 10.1007/s00253-014-6141-5

Luesken FA, van Alen TA, van der Biezen E, Frijters C, Toonen G, Kampman C, Hendrickx TLG, Zeeman G, Temmink H, Strous M, Op den Camp HJM, and Jetten MSM. 2011a. Diversity and enrichment of nitrite-dependent anaerobic methane oxidizing bacteria from wastewater sludge. Appl Microbiol Biotechnol 92:845-854. 10.1007/s00253-011-3361-9 476:43-50. 10.1038/nature10322

317 Raghoebarsing AA, Pol A, van de Pas-Schoonen KT, Smolders AJ, Ettwig KF, Rijpstra WI, Schouten S, Damste JS, Op den Camp HJ, Jetten MS, and Strous M. 2006. A microbial consortium couples anaerobic methane oxidation to denitrification. Nature 440:918-921. 10.1038/nature04617 
320 Ryan J, Estefan G, and Rashid A. 2007. Soil and plant analysis laboratory manual: ICARDA.

321 Segarra KEA, Comerford C, Slaughter J, and Joye SB. 2013. Impact of electron acceptor availability on the 322 anaerobic oxidation of methane in coastal freshwater and brackish wetland sediments. Geochimica et 323 Cosmochimica Acta 115:15-30. 10.1016/j.gca.2013.03.029

324 Shen L-d, Liu S, He Z-f, Lian X, Huang Q, He Y-f, Lou L-p, Xu X-y, Zheng P, and Hu B-1. 2015. Depth325 specific distribution and importance of nitrite-dependent anaerobic ammonium and methane-oxidising 326 bacteria in an urban wetland. Soil Biology and Biochemistry 83:43-51.

327 http://dx.doi.org/10.1016/j.soilbio.2015.01.010

328 Shen L-d, Liu S, Huang Q, Lian X, He Z-f, Geng S, Jin R-c, He Y-f, Lou L-p, and Xu X-y. 2014a. Evidence for the cooccurrence of nitrite-dependent anaerobic ammonium and methane oxidation processes in a

331

332

333

334

335

336

337

338

339

340 341 flooded paddy field. Applied and environmental microbiology 80:7611-7619.

Shen L-d, Qun Z, Shuai L, Ping D, Jiang-ning Z, Dong-qing C, Xiang-yang X, Ping Z, and Bao-lan H. 2014 b. Molecular evidence for nitrite-dependent anaerobic methane-oxidising bacteria in the Jiaojiang Estuary of the East Sea (China). Appl Microbiol Biotechnol 98:5029-5038. 10.1007/s00253-014-55563

Shu D, He Y, Yue H, Zhu L, and Wang Q. 2015. Metagenomic insights into the effects of volatile fatty acids on microbial community structures and functional genes in organotrophic anammox process. Bioresource Technology 196:621-633. 10.1016/j.biortech.2015.07.107

Smemo KA, and Yavitt JB. 2007. Evidence for Anaerobic CH4 Oxidation in Freshwater Peatlands. Geomicrobiology Journal 24:583-597. 10.1080/01490450701672083

Syakila A, and Kroeze C. 2011. The global nitrous oxide budget revisited. Greenhouse Gas Measurement and Management 1:17-26. 10.3763/ghgmm.2010.0007 
342 Tamura K, Dudley J, Nei M, and Kumar S. 2007. MEGA4: molecular evolutionary genetics analysis (MEGA)

343 software version 4.0. Molecular biology and evolution 24:1596-1599.

344 Timmers PHA, Suarez-Zuluaga DA, van Rossem M, Diender M, Stams AJM, and Plugge CM. 2015.

345 Anaerobic oxidation of methane associated with sulfate reduction in a natural freshwater gas source.

346 The ISME Journal 10:1400-1412. 10.1038/ismej.2015.213

347 Wang J, Zhang J, Wang J, Qi P, Ren Y, and Hu Z. 2011a. Nitrous oxide emissions from a typical northern

348 Chinese municipal wastewater treatment plant. Desalination and Water Treatment 32:145-152.

$349 \quad 10.5004 /$ dwt.2011.2691

350 Wang J, Zhang J, Xie H, Qi P, Ren Y, and Hu Z. 2011b. Methane emissions from a full-scale A/A/O

351 wastewater treatment plant. Bioresource Technology 102:5479-5485. 10.1016/j.biortech.2010.10.090

352 Wang Y, Zhu G, Harhangi HR, Zhu B, Jetten MSM, Yin C, and Op den Camp HJM. 2012. Co-occurrence and distribution of nitrite-dependent anaerobic ammonium and methane-oxidizing bacteria in a paddy soil. FEMS Microbiology Letters 336:79-88. 10.1111/j.1574-6968.2012.02654.x

Weiland BP. 2006. Biomass Digestion in Agriculture: A Successful Pathway for the Energy Production and Waste Treatment in Germany. Engineering in Life Sciences 6:302-309. 10.1002/elsc.200620128

Winkler MKH, Ettwig KF, Vannecke TPW, Stultiens K, Bogdan A, Kartal B, and Volcke EIP. 2015. Modelling simultaneous anaerobic methane and ammonium removal in a granular sludge reactor.

359 Water Research 73:323-331. 10.1016/j.watres.2015.01.039

Yan P, Li M, Wei G, Li H, and Gao Z. 2015. Molecular Fingerprint and Dominant Environmental Factors of Nitrite-Dependent Anaerobic Methane-Oxidizing Bacteria in Sediments from the Yellow River Estuary, China. Plos One 10:e0137996. 10.1371/journal.pone.0137996

363 Zhang T, Shao, M.-F., Ye, L., 2011. 454 Pyrosequencing reveals bacterial diversity of activated sludge from 14 sewage treatment plants. ISME J. 6, 1137-1147.

365 Zhou LL, Wang Y, Long XE, Guo JH, Zhu GB. 2014. "High abundance and diversity of nitrite-dependent 

$33-41$.

368

369 


\section{Table 1 (on next page)}

\section{Environmental characteristics}

Environmental characteristics of the sample sites. 
1 Distribution and characteristic of nitrite-dependent anaerobic methane oxidation bacteria in wastewater

2 treatment plants and agriculture fields in northern China

3 Zhen $\mathrm{Hu}^{\mathrm{a}, *}, \mathrm{Ru} \mathrm{Ma}^{\mathrm{a}}$

4 a School of Environmental Science and Engineering, Shandong University, Jinan, Shandong, China.

5 Corresponding Author:

6 Zhen $\mathrm{Hu}$

7 No. 27 Shanda South Road, Jinan, Shandong 250100, China

8 E-mail: huzhen885@s,su.edu.cn 
9 Table 1. Environmental characteristics of the sample sites.

\begin{tabular}{cccccccc}
\hline $\begin{array}{c}\text { Sample } \\
\text { sites }\end{array}$ & $\begin{array}{c}\text { Geographic } \\
\text { coordinates }\end{array}$ & $\begin{array}{c}\text { Temperature } \\
\left({ }^{\circ} \mathrm{C}\right)\end{array}$ & $\mathrm{pH}$ & $\begin{array}{c}\text { Ammonium } \\
\text { (mg N/kg } \\
\text { dry sed) }\end{array}$ & $\begin{array}{c}\text { Nitrite } \\
\text { (mg N/kg dry } \\
\text { sed) }\end{array}$ & $\begin{array}{c}\text { Nitrate } \\
\text { (mg N/kg dry } \\
\text { sed) }\end{array}$ & $\begin{array}{c}\text { Salinity } \\
\text { (\%o) }\end{array}$ \\
\hline PF & $\begin{array}{l}\mathrm{N} 36^{\circ} 41^{\prime}, \\
\mathrm{E} 116^{\circ} 54^{\prime}\end{array}$ & 17 & 7.3 & 10.34 & 0.75 & 26.97 & 1.8 \\
$\mathrm{CF}$ & $\begin{array}{l}\mathrm{N} 37^{\circ} 44^{\prime}, \\
\mathrm{E} 115^{\circ} 40^{\prime}\end{array}$ & 15 & 7.0 & 2.627 & 0.37 & 46.44 & 1.1 \\
$\mathrm{NC}$ & $\begin{array}{l}\mathrm{N} 36^{\circ} 40^{\prime}, \\
\mathrm{E} 117^{\circ} 03^{\prime}\end{array}$ & 32 & 7.0 & 0.125 & 14117.65 & 941.18 & 1.2 \\
$\mathrm{NS} 36^{\circ} 42^{\prime}$, & 22 & 7.6 & 815.88 & 127.19 & 735.29 & 2.1 \\
\hline
\end{tabular}

10

11

12 


\section{Figure 1}

FISH image of the collected samples.

Fig. 1- FISH image of the collected samples. The M. oxyfera bacteria was hybridized with probe S-*-DBACT-1027-a-A-18(Cy3, red) and total bacteria was hybridized with probes EUB IIII (FITC, green). a\&e, PF; b\&f, CF; c\&g, EC, d\&h, WS. The scale bar indicates $100 \mu \mathrm{m}$.

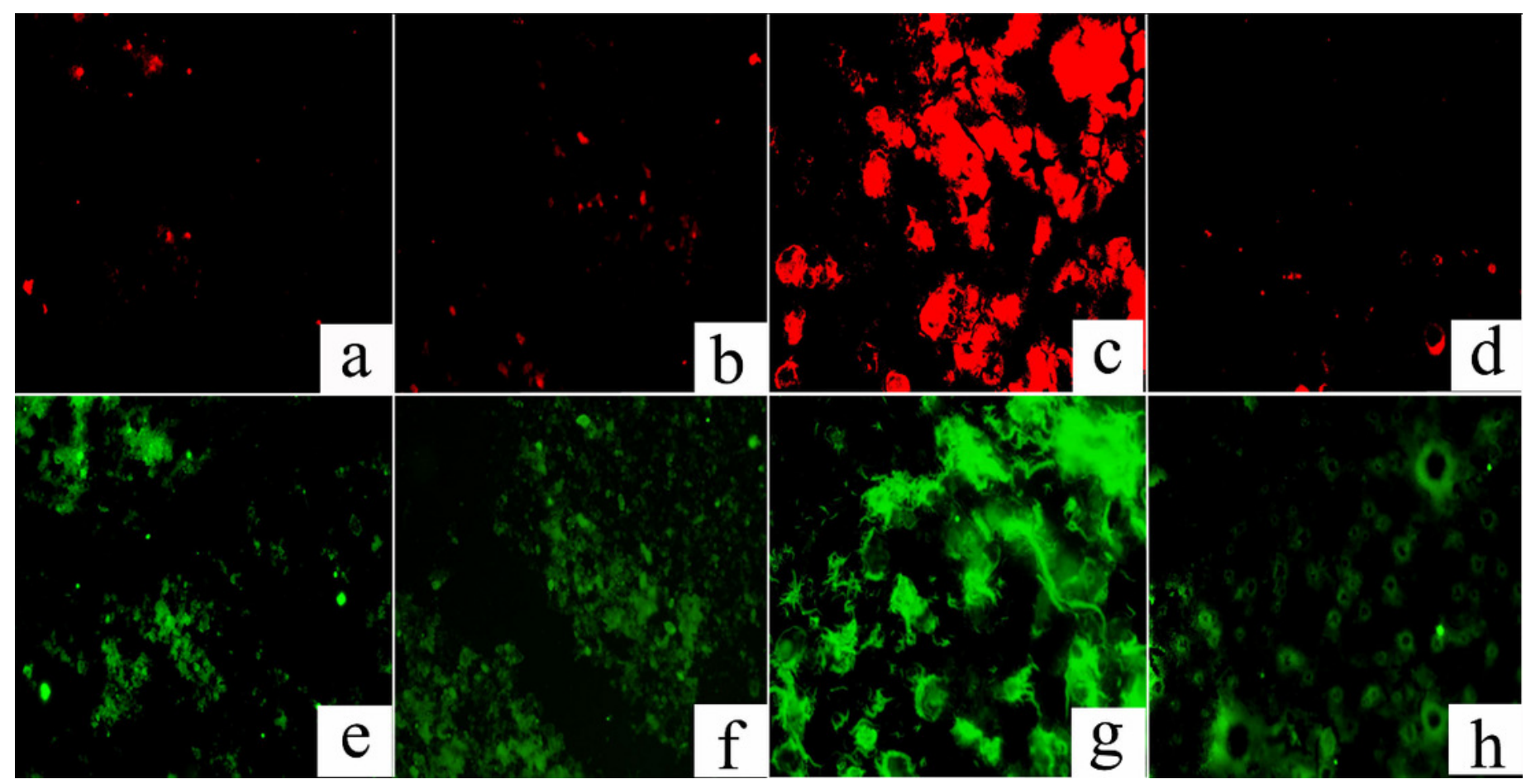


Figure 2

Q-PCR Image of $M$. oxyfera bacteria

Fig. 2- The abundance of M. oxyfera bacteria 16S rRNA gene copy numbers of collected samples.

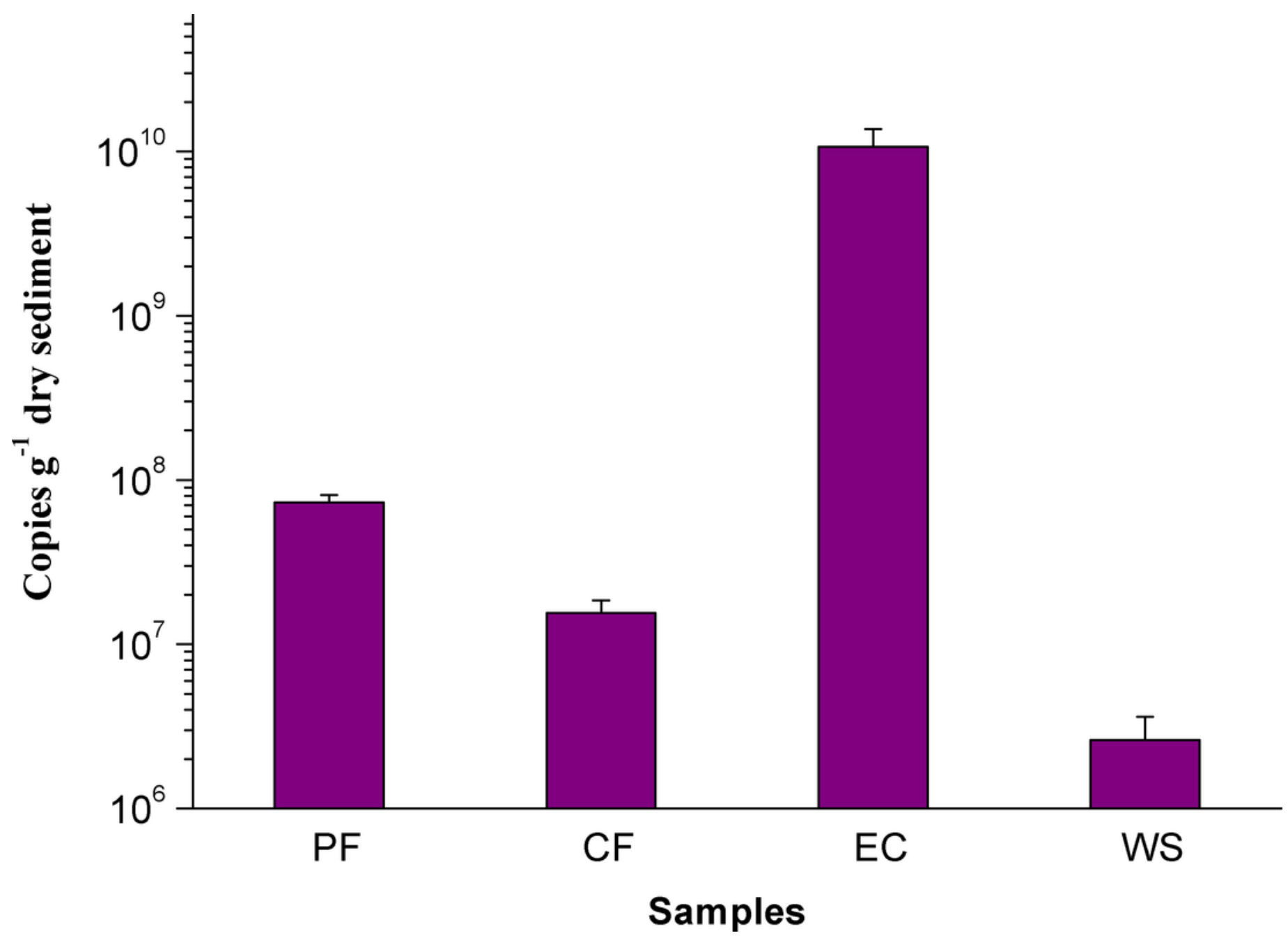


Figure 3

Image of batch test

Fig. 3 The consumption rates of methane and nitrite in the paddy field (a), corn field (b), ndamo enrichment culture (c), WWTP (d).
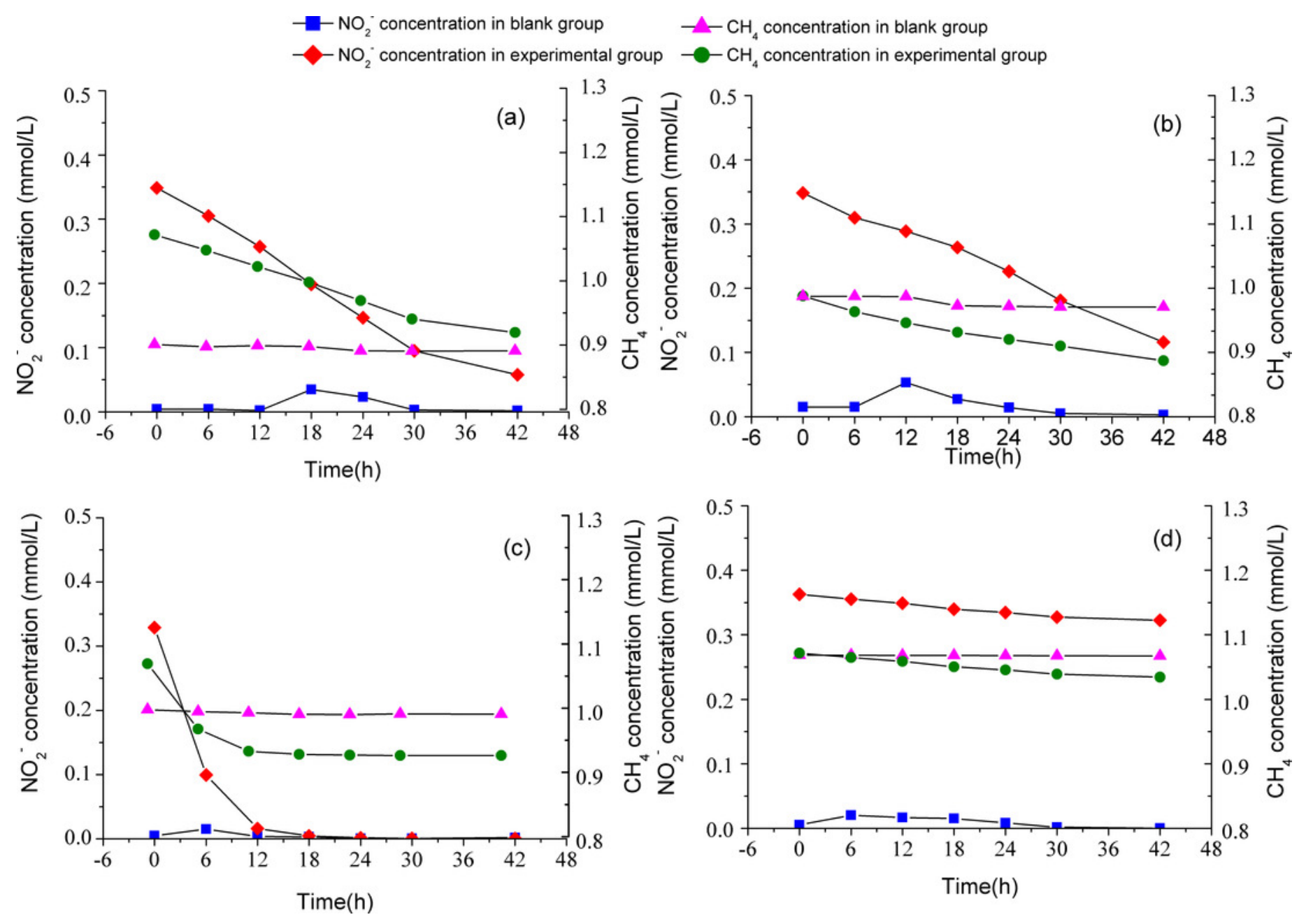


\section{Figure 4}

Composition of microbial community

Fig. 4 - Composition of microbial community at phylum level in different samples.

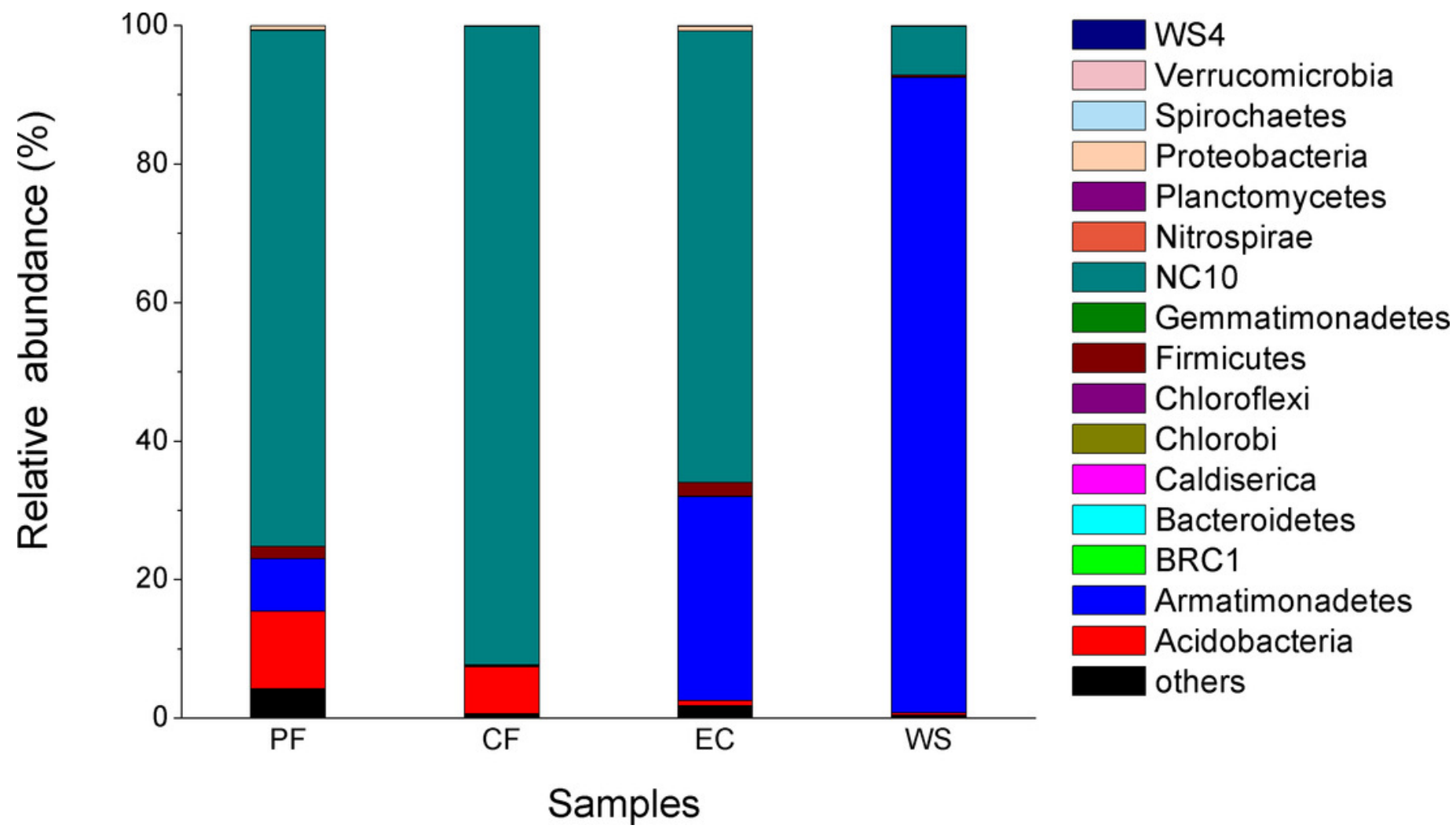


Figure 5

Richness heat map

Fig. 5 - Richness heat map of the 25 most abundant genera. 


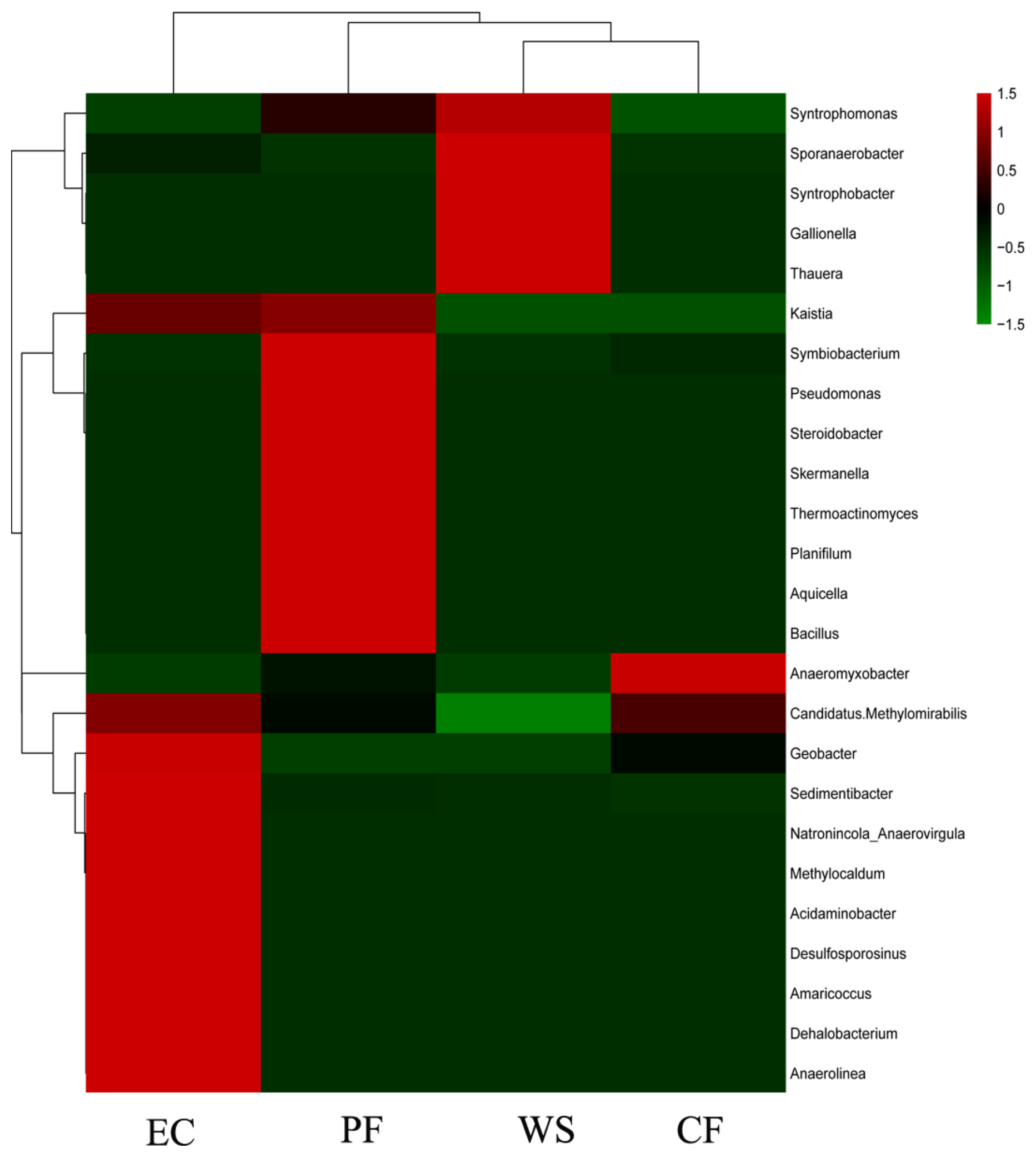

